\title{
Comprehensive Development Evaluation System of Asian Infrastructure Investment Bank Based on Double Diamond Model
}

\author{
Min Lu, Zhiping Wu, Qingjun Meng \\ (Affiliation): Business School, Hohai University, Nanjing, China \\ Email: 1252170643@qq.com
}

Received 26 June 2015; accepted 28 July 2015; published 31 July 2015

Copyright (C) 2015 by authors and Scientific Research Publishing Inc.

This work is licensed under the Creative Commons Attribution International License (CC BY). http://creativecommons.org/licenses/by/4.0/

c) (i) Open Access

\begin{abstract}
The establishment of Asian Infrastructure Investment Bank (AIIB) is China's first attempt to play a leading role in an international development agency, as well as an important deployment of international political and economic strategy in the new era. This article makes a comprehensive development evaluation on the newly-established bank based on Double Diamond Model. Main factors during the process are capabilities, demand conditions, relevant and supporting industries, business strategies, structures and competitions in the industry, government, and opportunity. Finally, concerns and countermeasures will be proposed according to the assessment.
\end{abstract}

\section{Keywords}

AIIB, Double Diamond Model, Evaluation System, Countermeasures

\section{Introduction}

From APEC, the G20, to a China-led AIIB, this has become a hot topic both at home and abroad. AIIB is the world's first professional, regional, quasi-commercial-operation investment bank, which specializes in infrastructure services for the Asian region. Its capital investment will be more concentrated. Compared with Asia Development Bank (ADB), it pays more attention to the "hardware" in the field of railways, highways, bridges, ports, power, telecommunications, oil and gas transportation, particularly in some projects which do not conform to social security, environment claims and are denied by the ADB and the World Bank (WB). Many countries are in favor of the foundation of AIIB whose purpose is to provide funds for Asian Country's Infrastructure. Developing countries in Asia are in a period of rapid economic construction which is in a great demand for funds. According to forecast of ADB, the Asian economy needs $\$ 8$ trillion for internal infrastructure, $\$ 300$ bil- 
lion for regional infrastructure between 2010 and 2020. However, ADB only provides about \$13 billion per year in new loans and new projects [1]. In addition, AIIB helps China absorb the excess production capacity and help Chinese enterprises to gradually realize the internationalization. Radiation area of AIIB is not confined to Asia, but also many developed countries, such as Britain, France and Germany and Italy.

Nevertheless, we also need to note that the establishment of an inter-governmental regional multilateral development institution is not a simple matter. Reasonable rules and governance structures, coordination and cooperation among members are necessary, which may lead to many difficulties and challenges. For example, contradictory national interests, instability in some areas, are an inadequate financial management experience. Academe is quite concerned about the issue, and it is of great value to establish a comprehensive evaluation of AIIB and find out some possible countermeasures to solve the potential problems.

\section{Relevant Research}

Establishment and development of AIIB has attracted close attention of domestic scholars and relevant departments. Jiwei Lou (2014) makes a brief description on differences between AIIB and other development banks; he believes AIIB is a new member and partner in the field of international development when there is a huge infrastructure financing demand in Asia [2]. Zhiyong Huang, Kwong and Jie Yan (2013) sum up the successful experience of the WB in terms of investment management, credit evaluation mechanism, and put forward some recommendations to build AIIB [3].

Effect of AIIB is not limited in Asia. Leo Melamed, Father of financial futures, noted that China's leading the initiative is worth cheering. Economy of Asia accounts for 33\% of the world. [4]. After Britain's application for entering AIIB, the professor of University of Western Australia, Mark Beeson makes the following comments (2015), Britain's decision is really a key of the current new international order.

Based on the above point of view, domestic scholars have discussed issues on system design, risk management, product risk, while foreign scholars mainly makes comments on attitude from different countries. Therefore, establishment of comprehensive evaluation system of AIIB which is still in lack.

\section{Comprehensive Development Evaluation Model and Index System}

The nature of intergovernmental regional multilateral development determines that it must face the complex international markets. Therefore, the comprehensive evaluation model should have a global horizon and combine the domestic with international environment. Michael Porter proposed a national competitive advantage theory that notes a country's competitive advantage is based on a set of basic factors-production factors, demand conditions, relevant and supporting industries and corporate strategy, as well as some cofactors. Various factors interact and influence each other to form a country's internal and external environment of business growth [5].

\subsection{Comprehensive Development Evaluation System of AIIB-Dynamic Double Diamond Model}

Double Diamond is based on Diamond theory, by Michael Porter, with 4 key factors, namely the factors of production, demand conditions, related and supporting industries and business strategy, structure and competition; Its 2 auxiliary elements are the opportunity and the government. Considering the existing models as well as AIIB its own characteristics, comprehensive evaluation model of AIIB is divided into 7 areas that contains 4 main and 2 auxiliary elements in Porter's diamond theory as well as its own capacity [6].

Double Diamond model was first proposed by Rugman and Verbeke (1998) to analyze the impact of crossborder mergers and acquisitions ( $\mathrm{M} \& \mathrm{~A}$ ) on the country's competitiveness, and to consider cross-border M \& A activity in these specific factors. Common with cross-border investment, AIIB focuses on international investment and unidirectional evaluation system is obviously outmoded. Double Diamond Theory makes up for this defect in which we can't balance both at home and abroad, so that we can understand it more comprehensively and thoroughly (Figure 1).

\subsection{Elements of the Dynamic Double Diamond Model}

\subsubsection{Capacity}

The capacity means financial management and investment screening level. China is not rich in experience, at the 


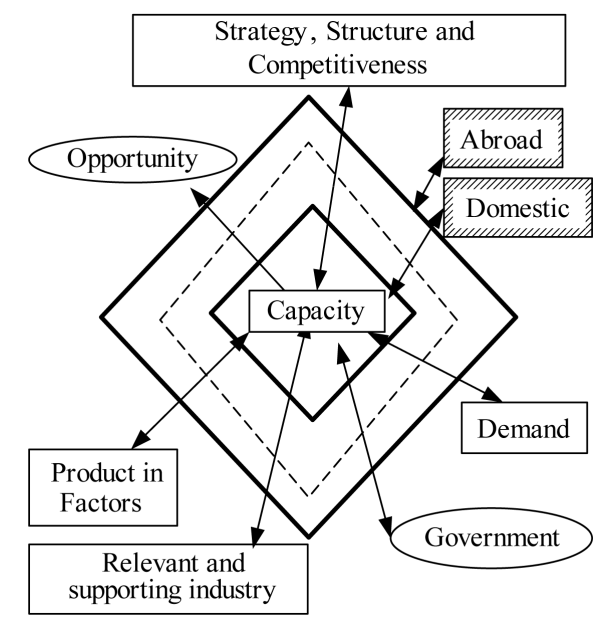

Figure 1. Comprehensive development evaluation system of AIIB of double diamond model.

same time, most members are developing countries, consequently, the degree of openness of financial sector is not so high. It is difficult that financial management of AIIB get full recognition from developed countries. Besides, projects concentrate mainly in investment areas with a long cycle of infrastructure and in developing regions where polity is instable. That indicates the risk of AIIB is relatively high because of both market and high political risk. This is actually a world-class problem. For example, continuous risk of default exist in the WB and International Monetary Fund (IMF) loans in Asia, Africa and some other countries, thus resulting in failure in get back a large number of loans, triggering a conflict in ideology and identity confrontation.

\subsubsection{Production Factors}

Generally, production factors refer to labor, land, capital and entrepreneurship, in which capital is the most significant. According to "The Preparation and the Investment Memorandum for AIIB" signed in 2014, the authorized capital of AIIB is $\$ 100$ billion with initial capital contribution of about $\$ 50$ billion and the registered capital is paid by the members by installments. ADB was established in 1963 with registered capital of $\$ 160$ billion, and the early payment is $\$ 100$ billion. In addition, Japan recently announced a $\$ 110$ billion to provide assistance to the Asian infrastructure projects planned. Therefore, the scale of funds of AIIB does not demonstrated outstanding advantages. However, considering ultimately founding member (57) and more countries as an ordinary member, far more than the ADB, there is still a great future for scale of development funds.

\subsubsection{Demand Factors}

Demand condition is a sufficient. The estimate amount of international institutional infrastructure needs for the Asia-Pacific region has been studied, the United Nations Economic and Social Commission for Asia and the Pacific, WB and other institutions have been published relevant research reports, and the Development Bank Institute for Asia and the Pacific 30 development economies in 2010-infrastructure (transport, electricity, telecommunications, water and sanitation facilities). Demand 2020 were evaluated. The results showed that between 2010 and 2020, total demand of Asia-Pacific infrastructure is about $\$ 8$ trillion, where new demand accounted for $68 \%$ of and maintenance updates demand accounted for $32 \%$, annual average infrastructure investment approximately needs $\$ 730$ billion.

\subsubsection{Relative and Supporting Industry}

Here, relevant and supporting industry is mainly China's manufacturing. According to a recent WB statistics, in 2013, in merchandise trade (including agriculture, fuel and minerals and manufactured goods), manufacturing exports ratio was $94.09 \%$. A number of companies, whose products are gradually being recognized by people all over the world. For example, China's rail transportation equipment and technology has been completely transformed. By 2014, exports value of CNR, CSR was both more than $\$ 3$ billion, with an increase of more than $60 \%$. These phenomena show that visibility and recognition of industrial brand in developing countries is rapidly in- 
creasing, with high degree of close cooperation and constantly jumped industrial level.

\subsubsection{Business Strategy, Structure and Competition}

As an inter-governmental regional development agency, ADB's main purpose is to help developing members in the Asia-Pacific region to eradicate poverty and promote economic and social development through fund assistance, particularly in the field of infrastructure, energy, environmental protection, education and health. From this perspective, there is an overlap between AIIB and other agencies. On governance structure, a sound internal governance structure can not only reduce operating costs, but also promote entrepreneurial talent management. According to "AIIB Charter", the bank requests an unpaid, non-resident board of directors to oversee the bank, different with WB and the ADB. If AIIB can fulfill the principle, it can provide a new paradigm for multilateral development institutions, promote structural reform of the governance of multilateral institutions and improve the global pattern.

\subsubsection{Opportunity and Government}

In recent years, the Chinese government continues to make great efforts to get more right in WB, IMF and WTO, but the ultimate effect is limited. The establishment of AIIB is a signal of major emerging economies starting outside "Bretton Woods". From the angle of the responsibility of the international community, China provides international public goods and promotes the development of the country's economic development, which reflects international responsibility of a big country. Many developing countries have made great achievements after decades of economic construction. Taking China's foreign exchange reserves as an example, it is up to $\$ 4.3$ trillion through years of accumulation. China has the financial capacity to export capital and rescuing other developing countries. It is in ample supply and demand of funds and a new international financial that the idea of AIIB emerged.

\section{Comprehensive Development Evaluation System of AIIB}

\subsection{Establishment of Index System}

The paper selects AHP (Analysis Hierarchical Process) as the method of evaluation system. The analysis method is proposed by operational research experts T. L. Saaty when dealing with complex issues of the evaluation, which is characterized by factorization complex problem, and pair wise comparison assessment of the importance [7]. Here, we establish, from high to low, comprehensive assessment development system divided into four selected indicators. We quantify the qualitative indicators by Delphi method. The index system (Table 2) is based on Yingqi Liu's overses markets for Chinese engineering contractors selection model and Xuewen Li's level of financial development in China for the evaluation and empirical analysis of the index set.

\subsection{Weights Determination}

Determining the weights is in the core position of AHP, directly affecting the effectiveness of an evaluation system. The following paragraph states in detail the progress of determining weights. It is divided into two steps, namely, judgment matrix and assignment, single-level sorting (calculation of weight vector).

\subsubsection{Judgment Matrix and Assignment}

Firstly, we analyze the importance between the two elements through consulting experts, its assignment in accordance with 1 - 9 importance scale values. (Table 1)

Secondary indicators show as follows (Table 2), through the experts' $n \times(n-1) / 2$ comparison. In the process of constructing this judgment matrix configuration, reference is fuzzy comprehensive evaluation model of infrastructure project investment risk by Gaoping Zhou, Ping Zhou and Yuanxiang Chen. In addition, Study of macro-political and economic environment in the new research assistance Jia Xu is additional reference.

\subsubsection{Hierarchical Single Sorting and Inspection}

After experts' judgment matrix fills out, we can make hierarchical orders in use of certain mathematical methods. Single-level sorting means relative weight for each factor of judgment matrix, it is essentially the weight vector computing. There are several ways to calculate the weight vector, such as product method, root method, power 
Table 1. The importance of scale.

\begin{tabular}{cl}
\hline Degree of Importance & Meaning \\
\hline 1 & Equally important \\
3 & The former is slightly more important than the latter \\
7 & The former is apparently more important than the latter \\
9 & The former is extremely more important than the latter \\
$2,4,6,8$ & Intermediate values \\
Inverse & If the importance ratio of $i$ and $j$ is $a_{i j}$, the ratio of $\mathrm{j}$ and $\mathrm{I}$ is $a_{j i}=1 / a_{i j}$ \\
\hline
\end{tabular}

Table 2. Secondary indicators judgment Matrix G-B.

\begin{tabular}{cccccccc}
\hline G & B1 & B2 & B3 & B4 & B5 & B6 & B7 \\
\hline B1 & 1 & 2 & 1 & 2 & $1 / 3$ & 2 & 1 \\
B2 & $1 / 2$ & 1 & $1 / 2$ & 1 & $1 / 2$ & 2 & 1 \\
B3 & 1 & 2 & 1 & 1 & $1 / 2$ & 3 & $1 / 2$ \\
B4 & $1 / 2$ & 1 & 1 & 1 & 1 & 2 & 1 \\
B5 & 3 & 2 & 2 & 1 & 1 & 3 & 1 \\
B6 & $1 / 2$ & $1 / 2$ & $1 / 3$ & $1 / 2$ & $1 / 3$ & 1 & $1 / 2$ \\
B7 & 1 & 1 & 2 & 1 & 1 & 2 & 1 \\
\hline
\end{tabular}

method and here is the root method.

(1) Calculation of judgment matrix elements of each row plot Mi.

$$
M_{i}=\prod_{j=1}^{7} B_{i j}(i=1,2,3, \cdots, 7) .
$$

Here, $B_{i j}$ stand for data in Table 2. For example, in line $1, B_{11}=1, B_{12}=2, B_{13}=1, B_{14}=2, B_{15}=1 / 3, B_{16}=2$, $B_{17}=1, M_{1}=8 / 3$.

Then, $M_{2}=1 / 4, M_{3}=3 / 2, M_{4}=1, M_{5}=36, M_{6}=1 / 144, M_{7}=4$.

(2) Calculation of $W_{i}\left(n\right.$th roots of $\left.M_{i}\right) . W_{i}=\sqrt[7]{M_{i}} \cdot W_{1}=1.15, W_{2}=0.82, W_{3}=1.06, W_{4}=1.00, W_{5}=1.67$, $W_{6}=0.49, W_{7}=1.22$.

(3) Vector normalization. $W=\sum_{i=1}^{7} W_{i}=W_{1}+W_{2}+W_{3}+W_{4}+W_{5}+W_{6}+W_{7}=7.41$. Then, $U_{i}=W_{i} / W$.

$U_{1}=0.16, U_{2}=0.11, U_{3}=0.14, U_{4}=0.13, U_{5}=0.23, U_{6}=0.07, U_{7}=0.16 . W=(0.16,0.11,0.14,0.13,0.23$, $0.07,0.16)^{\mathrm{T}}$

(4) Calculation of maximum eigenvalue $\lambda_{\max }$.

$A W=(1.16,0.80,1.05,0.99,1.70,0.47,1.21)$

$\lambda_{\max }=[1.16 / 0.16+0.80 / 0.11+1.05 / 0.14+0.99 / 0.13+1.70 / 0.23+0.47 / 0.07+1.21 / 0.16] / 7=7.34$

(5) Consistency check. Firstly, we calculate the consistency index CI (consistency index).

C.I. $=\left(\lambda_{\max }-n\right) /(n-1)=0.0573$.

According to the following table, an average random consistency index RI. For example, the 7-order judgment matrix, look-up table RI $=1.36$.

Second, we calculate the consistency ratio CR (consistency ratio) and make the judgment. C.R. = C.I./R.I) = $0.0421<0.1$, that means consistency of judgment matrix is acceptable. So it is with secondary and tertiary index weight coefficient, the results in Table 3.

\subsection{A Brief Description of Evaluation System}

Comprehensive evaluation of the development contains 7 aspects, namely capacity, production factor, demand 
Table 3. Comprehensive development evaluation and weight of AIIB.

\begin{tabular}{|c|c|c|}
\hline First Grade Indexes (B) & Secondary Indexes (C) & Tertiary Indexes (D) \\
\hline \multirow{6}{*}{ Capacity B1 (0.16) } & \multirow{4}{*}{$\begin{array}{l}\text { Internal Diamond Model Index } \\
\text { C11 (0.33) }\end{array}$} & Securitization Rate (China) D111 (0.21) \\
\hline & & Monetary Ratio (China) D112 (0.21) \\
\hline & & The Contribution of Financial Development (China) D113 (0.24) \\
\hline & & Level of Financial Regulation (China) D114 (0.34) \\
\hline & \multirow{2}{*}{$\begin{array}{l}\text { External Diamond Model Index } \\
\text { C12 (0.67) }\end{array}$} & Investment Project Selection Criteria D121 (0.67) \\
\hline & & Financial InnovationD122 (0.33) \\
\hline \multirow{4}{*}{$\begin{array}{l}\text { Production Factors } \\
\text { B2 (0.11) }\end{array}$} & \multirow{2}{*}{$\begin{array}{l}\text { Internal Diamond Model Index } \\
\text { C21 (0.50) }\end{array}$} & Fiscal Income (China) D211 (0.50) \\
\hline & & Scale of Private Capital (China) D212 (0.50) \\
\hline & \multirow{2}{*}{$\begin{array}{l}\text { External Diamond Model Index } \\
\text { C22 (0.50) }\end{array}$} & Fiscal Income (Other) D221 (0.50) \\
\hline & & Scale of Private Capital (Other) D222 (0.50) \\
\hline \multirow{6}{*}{$\begin{array}{l}\text { Demand Conditions } \\
\text { B3 }(0.14)\end{array}$} & \multirow{3}{*}{$\begin{array}{l}\text { Internal Diamond Model Index } \\
\text { C31 (0.33) }\end{array}$} & Infrastructure Growth (China) D311 (0.49) \\
\hline & & Urbanization Level (China) D312 (0.20) \\
\hline & & Infrastructure Financing Diversification (China) D313 (0.31) \\
\hline & \multirow{3}{*}{$\begin{array}{l}\text { External Diamond Model Index } \\
\text { C32 (0.67) }\end{array}$} & Infrastructure Growth (Others) D321 (0.49) \\
\hline & & Urbanization Level (Others) D322 (0.20) \\
\hline & & Infrastructure Financing Diversification (Others) D323 (0.31) \\
\hline \multirow{7}{*}{$\begin{array}{l}\text { Relevant and } \\
\text { Supporting Industry } \\
\text { B4 (0.13) }\end{array}$} & \multirow{4}{*}{$\begin{array}{l}\text { Internal Diamond Model Index } \\
\text { C41 (0.50) }\end{array}$} & Annual Output Value of Manufacturing (China) D411 (0.28) \\
\hline & & Market Technical Specifications \& Standards (China) D412 (0.19) \\
\hline & & Infrastructure Engineering Insurance Claims (China) D413 (0.14) \\
\hline & & RMB Exchange Rate Stability D414 (0.39) \\
\hline & \multirow{3}{*}{$\begin{array}{l}\text { External Diamond Model Index } \\
\text { C42 (0.50) }\end{array}$} & Reserves of Related Countries D421 (0.49) \\
\hline & & Infrastructure Restrictions of Relevant Countries D422 (0.20) \\
\hline & & Countries Sovereign Credit Rating Situation D423 (0.31) \\
\hline \multirow{3}{*}{$\begin{array}{l}\text { Business Strategy, Instruction } \\
\text { and Competitiveness } \\
\text { B5 }(0.23)\end{array}$} & $\begin{array}{l}\text { Internal Diamond Model Index } \\
\text { C51 (0.67) }\end{array}$ & $\begin{array}{l}\text { Rationality of Strategy and Governance Structure of } \\
\text { AIIBD511 (1.00) }\end{array}$ \\
\hline & \multirow{2}{*}{$\begin{array}{l}\text { External Diamond Model Index } \\
\text { C52 (0.33) }\end{array}$} & Horizontal Competition D521 (0.67) \\
\hline & & Partners D522 (0.33) \\
\hline \multirow{2}{*}{$\begin{array}{l}\text { Opportunity } \\
\text { B6 (0.07) }\end{array}$} & $\begin{array}{l}\text { Internal Diamond Model Index } \\
\text { C61 (0.50) }\end{array}$ & Chinese Domestic Reform and Opening-up Situation D611 (1.00) \\
\hline & $\begin{array}{l}\text { External Diamond Model Index } \\
\text { C62 (0.50) }\end{array}$ & Opening Circumstances of Relevant Areas D621 (1.00) \\
\hline \multirow{4}{*}{$\begin{array}{l}\text { Government } \\
\text { B7 (0.16) }\end{array}$} & \multirow{2}{*}{$\begin{array}{l}\text { Internal Diamond Model Index } \\
\text { C71 (0.50) }\end{array}$} & Political Stability (China) D711 (0.33) \\
\hline & & Support from Chinese Government D712 (0.67) \\
\hline & \multirow{2}{*}{$\begin{array}{l}\text { External Diamond Model Index } \\
\text { C72 (0.50) }\end{array}$} & Political Stability (Others) D721 (0.33) \\
\hline & & International Support D722 (0.67) \\
\hline
\end{tabular}

conditions, relevant and supporting industries, business strategy, structure and competition, opportunities and government. Obviously, the 7 aspects are not of the same importance. Among them, the business strategy, structure and competition has the highest proportion, about 0.23 ; then the following are capacity and govern- 
ment, each accounting for 0.16; finally, demand factors, related and supporting industries, factors of production, opportunity follow in order according to the proportion. Thus, AIIB's own strategy, governance structure and industry competition, is essential for its development. Considering the 3 indicators, AIIB's strategy, governance structure has percentage of $15.41 \%$, the largest share.

\subsection{Application of Evaluation System}

Since the comprehensive evaluation has been set up, we ask experts make assessment through questionnaire, and the total score is 100. Firstly, experts grade tertiary indexes (average and round); secondly, we add the scores of tertiary index which belong to the same secondary indicators; Then, It is the same with first grade indexes. A detailed description of scores can be seen from Figure 2, and the final score of 81.44.

\section{Concerns and Countermeasures during Development of AIIB}

\subsection{Concerns during Development of AIIB}

In the process of making comprehensive evaluation of AIIB, importance need to be attached to some problems, since some of the scores are not high. Factors of Internal Diamond are as follows. For example, China's financial sector development and supervision needs to be improved; leading country-China's infrastructure construction and technical specifications and insurance industry needs to be strengthened. The External Diamond includes project selection criteria rationality, low levels of fiscal and private capital of developing countries (there is downward pressure on the economy in EU countries). In addition, the relevant national political stability cannot be guaranteed.

\subsection{Countermeasures for the Problems}

\subsubsection{Founding Countries Continuing to Promote Domestic Financial Reform}

At the micro level, a number of large enterprises with financial strength and advanced technology can meet needs at home and abroad. However, the past of the "financial repression" affects the development of large enterprises, only through financial reform and innovation will the industries be able to realize their full potential. At the national level, Chinese enterprises' going out is an important measure to build a new system of open economy, the expansion of foreign investment has become a national strategic. We should seek business model transformation, PPP, as an innovative infrastructure and public service delivery mechanisms, is becoming the preference in the field of infrastructure construction. AIIB will focus on the follow-up or the introduction of social capital and related technical training through PPP mode. Companies interested in investing in the country should be accumulated practical experience, guarantee PPP knowledge base as soon as possible [8].

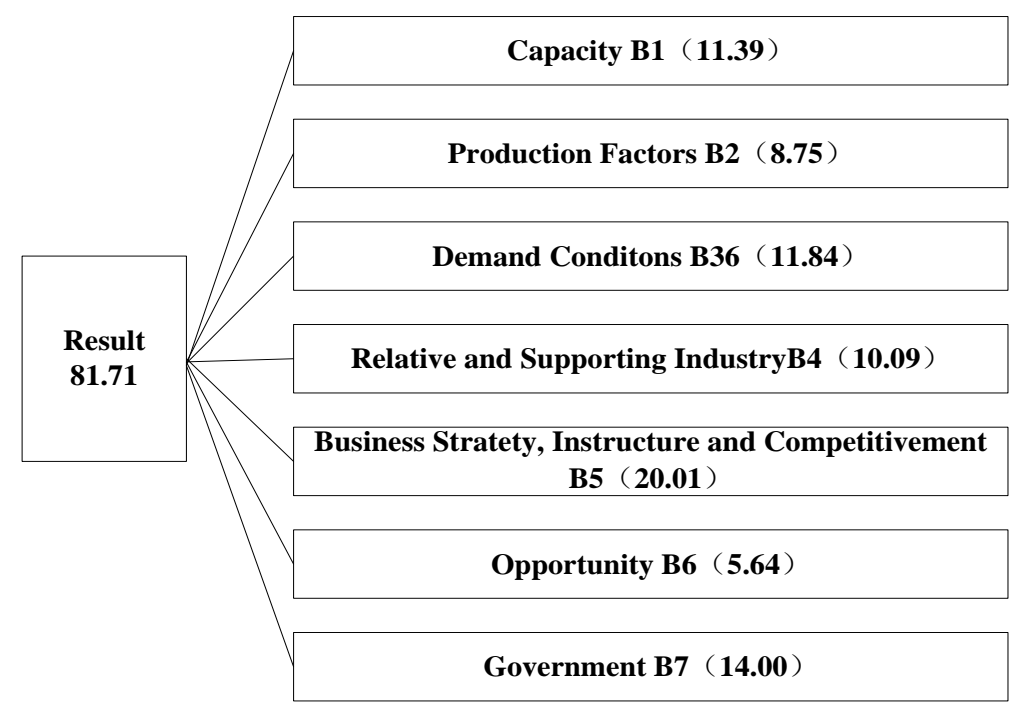

Figure 2. Results of comprehensive development evaluation system. 


\subsubsection{Improving the Supporting Role of Relative Industries}

Askey strategic initiative, the China government should pay more attention to it and introduce more policies to support the relevant business. For example, benchmark of interest rates and simplifying foreign investment approval procedure. In addition, the technical standards and harmonization of the international market will help improve the competitiveness of infrastructure and business insurance claims need to be further standardized. Insurance companies, fund companies and other private-sector social security funds and other institutional investors, and the public sector tend to have adequate funds, but it is difficult to seek to appropriate projects for them. We can build a communication platform to provide long-term stability of investment projects to these sectors. These investors can participate in fund shares in the form of bonds, stocks and other indirect support.

\subsubsection{The Establishment of Investment Projects Evaluation and Risk Tracking System}

As for principles of project selection, AIIB should regard settling down to sharing interests with the developing countries as the purpose. In addition, it needs to adhere to green economic development, instead of damaging the ecological environment. Second, what's more important is to make the world, especially developing countries share in employment, industrial upgrading, etc. In project risk monitoring and tracking, AIIB should draw on the experience and lessons of WB and other multilateral development institutions. Thirdly, AIIB needs to make institutional arrangements for accountability and loss allocation and investment project selection, to avoid sharing in losses, wrangling with each investment project selection and other issues, thereby affecting the AIIB for future funding.

\subsubsection{Carrying out International Cooperation with Other Development Agencies}

An active attitude is cooperation and openness, especially under the condition of capital constrained and inexperienced management. First, AIIB can learn from the experience, such as the decision-making mechanism, the project is running, positioning and other institutions, to avoid vicious competition. Secondly, the existing multilateral organizations, including WB and IMF also have infrastructure business. Groups' separation from each other will generate unhealthy competition. Only by seeking communication and cooperation, can we get maximum functionality. For example, WB and IMF concentrate on developed countries where developing countries do not have a great voice. Based on these facts, AIIB can carry out in-depth cooperation with WB, particularly in infrastructure projects in the field, especially in developing countries.

\subsubsection{Keeping Politics and Economy Balance}

Since it's first attempt to establish an international development agencies for China, China may find it difficult to keep balance of politics and economy. In preparation period, AIIB's headquartered preferred in Beijing. And it may set up a branch in the South Asian region such as Indian capital city, New Delhi. The branch in Southeast Asian region can be located in Jakarta. Branches in Central Asia may be located in Russia Moscow, which can substantially constituted to Beijing as the vertex, Moscow, New Delhi and Jakarta as the first line of an isosceles triangle, and expand the scope of radiation Asian investment bank [9]. Secondly, during operation period, infrastructure investment has the characteristics of long construction periods, slow return. There may be difficult construction issues such as political instability, especially at cross-border infrastructure projects. From the "economic man" perspective, it is clearly unreasonable. But from the national strategy or political point, quite a number of projects really have significant social impact in promoting regional interoperability.

\section{Conclusions}

With the expansion of infrastructure, establishment of AIIB welcomes the opportunity. The current world economic situation has undergone new changes, and the contribution of Asia in world economic growth is up to more than 50\%. Besides, developing and emerging market countries have accounted for more than $50 \%$ in the proportion of total global economy. In order to meet the growing financing needs, urgent need for multilateral financial agencies like AIIB is necessary.

Establishment and development of AIIB need support from all over the world. AIIB is designed to provide financing methods for infrastructure in developing countries, during which China needs to play an active role in advocacy and coordination and seeks for world cooperation on infrastructure investment. Therefore, establishment and development of AIIB need more common communication, co-operation and participation. 


\section{References}

[1] Zhou, X.Y. (2014) Committed to Serving the Asian Economic, Filling Gaps of International Financial System. http://paper.people.com.cn/rmrbhwb/html/2014-10/27/content 1492012.htm

[2] Xia, Z.J. (2014) Jiwei Lou: Injection Lasting Impetus for Economic Development in Asia. http://www.mof.gov.cn/zhengwuxinxi/caizhengxinwen/201410/t20141027_1154454.html

[3] Huang, Z.Y., Kuang, Z. and Yan, J. (2013) The World Bank’s Enlightenment to Build AIIB. Around Southeast Asia, 12, 4-12.

[4] Wang, X.D. (2015) Father of Financial Futures: AIIB Opens a New Door of Economic Growth in Asia. http://www.hi.chinanews.com/hnnew/2015-04-03/379946.html

[5] Porter, M. (2005) Competitive Advantage of Nations. Huaxia Publishing House, Beijing.

[6] Liu, Y.Q. (2004) Selection Model of China’s Contractors Overseas Markets. China soft Science Magazine, 10, 77-82. http://dx.doi.org/10.3969/j.issn.1002-9753.2004.10.012.

[7] Meng, Q.J., Zhang, J. and Wang, X.M. (2015) Extension Comprehensive Evaluation of SME Credit Risk. Science and Technology Management Research, 5, 59-67.

[8] Zhong, L. (2014) AIIB, New Infrastructure Investment Opportunities? Import and Export Managers, 12, 47-49. http://dx.doi.org/10.3969/j.issn.1673-6532.2014.12.012

[9] Sheng, S.X. and Cao, W.L. (2015) Geopolitical and Economic Analysis of Infrastructure of AIIB. Globalization, 1, 4960 . 